\title{
PENGARUH PENGGUNAAN ALAT KONTRASEPSI DAN MIGRASI PENDUDUK TERHADAP PERTUMBUHAN PENDUDUK DI PROVINSI SUMATERA UTARA
}

\author{
${ }^{1}$ Rizky Andrian, ${ }^{2}$ Zulkifli Siregar, ${ }^{3}$ M. Sahnan \\ ${ }_{1,2,3}$ Universitas Islam Sumatera Utara \\ ${ }^{1}$ rizky.andrian@gmail.com, ${ }^{2}$ zulkifli.siregar@fe.uisu.ac.id, ${ }^{3}$ sahnan@fe.uisu.ac.id
}

\begin{abstract}
In this study, population growth in North Sumatra Province has increased and decreased every year. This is due to the factors of the use of contraceptives and migration which have increased and decreased every year. The formulation of the problem in this study is how the Effect of Contraceptive Use and Population Migration on Population Growth in North Sumatra Province and is limited only to the use of contraceptives, population migration and population growth in North Sumatra Province in 2016-2020. The purpose of this study was to determine the effect of the use of contraceptives and population migration on population growth in the province of North Sumatra. The hypothesis in this study is that the use of contraceptives and population migration has an effect on population growth in the province of North Sumatra. The population of this study is the report on the Use of Contraceptive Devices, Population Migration and Population Growth in 2016-2020. The sample used is taken from the entire population, namely as many as 33 regencies/cities in North Sumatra Province and multiplied by 5 years in order to obtain 165 research samples. The analysis technique used is multiple regression analysis, $t$ test and $F$ test were conducted to test the effect partially and simultaneously between the independent variable and the dependent variable with the assumption that other variables are considered constant. Based on the results of the partial test, it is known that the variables of Contraceptive Device Use (X1) and Population Migration (X2) have an influence on Population Growth (Y). Based on the results of the simultaneous test, it was found that the Use of Contraceptive Devices (XI) and Population Migration (X2) had a simultaneous (simultaneous) effect on the Population Growth variable $(Y)$. Based on the results of the coefficient of determination test, the $R$ square value is 0.544 . This means that the effect of the independent variable on the dependent variable is $54.4 \%$, while the remaining 0.456 or $45.6 \%$ is influenced by other variables not included in this study.
\end{abstract}

Keywords: Use of Contraceptive Devices, Population Migration, Population Growth

ABSTRAK : Dalam penelitian ini pertumbuhan penduduk di Provinsi Sumatera Utara mengalami
peningkatan dan penurunan di setiap tahunnya. Hal ini dikarenakan faktor penggunaan alat
kontrasepsi dan migrasi yang mengalami peningkatan dan penurunan setiap tahunnya. Rumusan
masalah pada penelitian ini yaitu bagaimana Pengaruh Penggunaan Alat Kontrasepsi dan Migrasi
Penduduk Terhadap Pertumbuhan Penduduk Di Provinsi Sumatera Utara dan dibatasi hanya
mengenai penggunaan alat kontrasepsi, migrasi penduduk dan pertumbuhan pendudu di Provinsi
Sumatera Utara Tahun 2016-2020. Tujuan dari penelitian ini yaitu untuk mengetahui Pengaruh
Penggunaan Alat Kontrasepsi dan Migrasi Penduduk Terhadap Pertumbuhan Penduduk di
Provinsi Sumatera Utara. Hipotesis pada penelitian ini yaitu diduga Penggunaan Alat Kontrasepsi
dan Migrasi Penduduk berpengaruh Terhadap Pertumbuhan Penduduk Di Provinsi Sumatera
Utara. Populasi penelitian ini adalah laporan Penggunaan Alat Kontrasepsi, Migrasi Penduduk
dan Pertumbuhan Penduduk Tahun 2016-2020. Sampel yang dipakai yaitu diambil dari seluruh
dari populasi yaitu sebanyak 33 Kabupaten/Kota yang ada di Provinsi Sumatera Utara dan di kali
5 tahun sehingga diperoleh 165 sampel penelitian. Teknik analisis yang digunakan adalah analisis
regresi berganda, uji t dan uji F dilakukan untuk menguji pengaruh secara parsial dan simultan
antara variabel independen dengan variabel dependen dengan asumsi bahwa variabel lain
dianggap konstan. Berdasarkan hasil pengujian secara parsial dikertahui bahwa variabel
Penggunaan Alat Kontrasepsi ( $X_{1}$ ) dan Migrasi Penduduk $\left(X_{2}\right)$ memiliki pengaruh terhadap 
Pertumbuhan Penduduk (Y). Berdasarkan hasil uji simultan diperoleh bahwa Penggunaan Alat Kontrasepsi $\left(X_{1}\right)$ dan Migrasi Penduduk $\left(X_{2}\right)$ berpengaruh secara bersama-sama (simultan) terhadap variabel Pertumbuhan Penduduk (Y). Berdasarkan hasil uji koefisien determinasi diperoleh nilai $R$ square sebesar 0.544. Hal ini berarti bahwa pengaruh variabel bebas terhadap variable terikat adalah sebesar $54.4 \%$, sedangkan sisanya sebesar 0.456 atau $45.6 \%$ dipengaruhi variable lain yang tidak dimasukkan dalam penelitian ini.

\section{Kata Kunci : $\quad$ Penggunaan Alat Kontrasepsi, Migrasi Penduduk, Pertumbuhan Penduduk}

\section{Pendahuluan}

Sebagai salah satu negara dengan laju pertumbuhan penduduk yang tinggi, negara Indonesia membutuhkan perhatian khusus dan penanganan yang tepat oleh pemerintah, karena akibat laju pertumbuhan penduduk yang tinggi pada kemudian hari akan memberikan dampak negatif bagi kesejahteraan masyarakat seperti angka kemiskinan yang terus meningkat karena laju pertumbuhan penduduk yang tinggi tidak diimbangi oleh pertumbuhan ekonomi, semakin maraknya permukiman kumuh di perkotaan, serta pemerintah juga akan mengalami kesulitan menyediakan sarana kebutuhan masyarakat seperti sarana pendidikan, sarana kesehatan, dan perumahan.

Seperti halnya yang diungkapkan oleh Badan Pusat Statistik (2011) $\square$ bahwa pertumbuhan penduduk sangat erat kaitannya dengan kesejahteraan penduduk dan salah satu provinsi di Indonesia yang menyumbang angka pertumbuhan penduduk tertinggi adalah Provinsi Sumatera Utara. Berdasarkan hasil pendataan penduduk pada tahun 2015, jumlah penduduk Provinsi Sumatera Utara mencapai 13.937.797 orang, yang terdiri atas 6.954.552 laki-laki dan 6.983.245 perempuan, dengan kepadatan rata-rata $186 \mathrm{Jiwa} / \mathrm{Km}^{2}$. Jumlah penduduk Provinsi Sumatera Utara juga merupakan yang terbesar keempat di Indonesia setelah Provinsi Jawa Barat, Jawa Timur, dan Jawa Tengah (Pemprov Sumut, 2017) $\square$.

Melihat hal tersebut tentunya menjadi perhatian khusus bagi pemerintah Provinsi Sumatera Utara. Meski bagi sebagian pengambil kebijakan, pertumbuhan penduduk yang meningkat dianggap tidak merisaukan. Namun bagi pemerintah Provinsi Sumatera Utara pertumbuhan penduduk yang meningkat tinggi seperti ini dianggap sebagai salah satu hambatan dalam mencapai tujuan pembangunan secara luas. Salah satu hal yang sangat dikhawatirkan adalah dampak dari perubahan jumlah penduduk akan mempengaruhi permintaan yang kemudian harus dipenuhi oleh sektor lainnya, misalnya penyediaan kebutuhan dasar seperti papan, pangan, dan pakaian. Untuk itu pemerintah Provinsi Sumatera Utara ingin melakukan ragam upaya untuk dapat menekan pertumbuhan penduduk dengan cara mengetahui faktor apa saja yang mempengaruhi pertumbuhan penduduk di Provinsi Sumatera Utara.

Menurut Sarsanto (2007: 81) $\square$ penggunaan alat kontrasepsi adalah salah satu faktor yang dapat mengendalikan pertumbuhan penduduk. Alat kontrasepsi adalah alat yang digunakan untuk menekan atau menunda kehamilan, dengan tertundanya kehamilan, maka hal ini akan berdampak terhadap pertumbuhan penduduk secara langsung, dimana pertumbuhan penduduk akan lebih teratur dan berjarak, sehingga tidak mengakibatkan terjadinya kepadatan penduduk diluar kendali.

Selain itu menurut Munir (2010: 103) migrasi juga menjadi faktor yang mempengaruhi pertumbuhan penduduk. Migrasi merupakan perpindahan penduduk dengan tujuan menetap dari suatu tempat ke tempat lain melampaui batas politik/negara ataupun batas administratif/batas wilayah dalam suatu negara. Migrasi sering diartikan sebagai perpindahan yang relatif permanen dari suatu daerah ke daerah lain. Adanya migrasi penduduk menjadi salah satu penyebab terjadinya pertumbuhan penduduk disuatu daerah maupun negara, semakin tinggi jumlah migrasi masuk, maka akan semakin tinggi pula pertumbuhan penduduk didaerah tersebut. Sehingga apabila migrasi penduduk masuk dapat diminimalisir, maka pertumbuhan penduduk akan dapat dikendalikan.

Sebagai sajian data yang lebih rinci tentang jumlah penggunaan alat kontrasepsi, jumlah migrasi penduduk masuk, dan laju pertumbuhan penduduk Provinsi Sumatera Utara periode 2016-2020 dapat dilihat pada Tabel 1. 
Tabel 1

Jumlah Penggunaan Alat Kontrasepsi, Jumlah Migrasi Penduduk Masuk, dan Laju Pertumbuhan Penduduk Provinsi Sumatera Utara

Periode 2016-2020

\begin{tabular}{|l|c|c|c|}
\hline Tahun & $\begin{array}{c}\text { Penggunaan Alat } \\
\text { Kontrasepsi } \\
\text { (Unit) }\end{array}$ & $\begin{array}{c}\text { Migrasi Penduduk } \\
\text { Masuk } \\
\text { (Orang) }\end{array}$ & $\begin{array}{c}\text { Pertumbuhan Penduduk } \\
\text { (\%) }\end{array}$ \\
\hline 2016 & 1.636 .590 & 123.908 & 1,20 \\
\hline 2017 & 1.708 .879 & 134.112 & 1,28 \\
\hline 2018 & 1.698 .650 & 131.197 & 1,26 \\
\hline 2019 & 1.711 .233 & 126.823 & 1,23 \\
\hline 2020 & 1.787 .659 & 116.619 & 1,13 \\
\hline
\end{tabular}

Berdasarkan Tabel 1 dapat dilihat bahwa jumlah penggunaan alat kontrasepsi selama periode 2016-2017 mengalami peningkatan hingga 1.708 .879 unit ditahun 2017, sedangkan ditahun 2018 mengalami penurunan hingga menjadi sebesar 1.698.650. Kemudian untuk jumlah migrasi penduduk masuk mengalami peningkatan diperiode 2016-2017 dari sebesar 123.908 orang ditahun 2016 hingga 134.112 orang ditahun 2017 sedangkan ditahun 20182020 terus mengalami penurunan dari 131.197 orang ditahun 2018 hingga 116.619 ditahun 2020. Untuk pertumbuhan penduduk juga demikian, yaitu mengalami peningkatan pada 2016-2017 dari 1,20\% ditahun 2016 hingga 1,28\% ditahun 2017 sedangkan ditahun 2018 terus mengalami penurunan dari sebesar $1,26 \%$ hingga 1,13\% ditahun 2020 .

Hal tersebut menunjukkan bahwa adanya hubungan antara jumlah penggunaan alat kontrasepsi dan jumlah migrasi penduduk masuk dengan pertumbuhan penduduk di Sumatera Utara. Karena saat jumlah penggunaan alat kontrasepsi dan jumlah migrasi penduduk masuk meningkat atau menurun, maka pertumbuhan penduduk juga mengalami hal yang sama.

\subsection{Rumusan Masalah}

Dari masalah yang teridentifikasi dalam penelitian ini dapat di rumuskan masalah sebagai berikut:

1) Bagaimanakah pengaruh penggunaan alat kontrasepsi terhadap pertumbuhan penduduk di Provinsi Sumatera Utara?
2) Bagaimanakah pengaruh migrasi penduduk terhadap pertumbuhan penduduk di Provinsi Sumatera Utara?

3) Bagaimanakah pengaruh penggunaan alat kontrasepsi dan migrasi penduduk terhadap pertumbuhan penduduk di Provinsi Sumatera Utara?

\subsection{Tujuan Penelitian}

Dari rumusan masalah dalam penelitian ini dapat diketahui bahwa tujuan dari penelitian ini adalah:

1) Untuk mengetahui pengaruh penggunaan alat kontrasepsi terhadap pertumbuhan penduduk di Provinsi Sumatera Utara.

2) Untuk mengetahui pengaruh migrasi penduduk terhadap pertumbuhan penduduk di Provinsi Sumatera Utara.

3) Untuk mengetahui pengaruh penggunaan alat kontrasepsi dan migrasi penduduk terhadap pertumbuhan penduduk di Provinsi Sumatera Utara.

\subsection{Hipotesis}

Berdasarkan kerangka konseptual dalam penelitian ini, maka dapat dibuat hipotesis sebagai berikut:

$\mathrm{H}_{1}$ : Penggunaan alat kontrasepsi berpengaruh negatif signifikan terhadap pertumbuhan penduduk di Provinsi Sumatera Utara

$\mathrm{H}_{2}$ : Migrasi penduduk berpengaruh positif signifikan terhadap pertumbuhan penduduk di Provinsi Sumatera Utara

$\mathrm{H}_{3}$ : Penggunaan alat kontrasepsi dan migrasi penduduk berpengaruh positif 
signifikan terhadap pertumbuhan penduduk di Provinsi Sumatera Utara

\section{Metode Penelitian}

\subsection{Populasi dan Sampel}

Adapun populasi dalam penelitian ini adalah seluruh kabupaten/kota yang terdapat di Provinsi Sumatera Utara dengan jumlah total sebanyak 33 kabupaten/kota. Berdasarkan jumlah populasi tersebut, maka teknik sampling yang digunakan adalah sampling jenuh. Menurut Sugiyono (2017: 85) $\square$ teknik sampling jenuh adalah teknik penentuan sampel dimana semua anggota populasi digunakan menjadi sampel, apabila jumlah populasi lebih kecil dari 100. Sehingga sampel dalam penelitian ini terdapat di Provinsi Sumatera Utara dengan jumlah total sebanyak 33 kabupaten/kota.

\subsection{Teknik Analisis Data}

Data yang digunakan dalam penelitian ini merupakan data sekunder, yaitu data yang diperoleh peneliti secara tidak langsung melalui media perantara (diperoleh dan dicatat oleh pihak lain). Data dalam penelitian ini didapatkan dan unduh melalui situs sumut.bps.go.id. Selain itu peneliti juga melakukan penelitian kepustakaan dengan memperoleh data yang berkaitan dengan pembahasan yang sedang diteliti melalui berbagai literatur seperti buku, jurnal, skripsi maupun situs internet. Ini dikarenakan kepustakaan merupakan bahan utama dalam penelitian data sekunder dan selanjutnya di uji dengan SPSS Versi 20.

\section{Hasil Dan Pembahasan Hasil Penelitian \\ 3.1. Uji Normalitas}

a. Pengujian Kolmogorof Smirnov

Uji Normalitas bertujuan untuk menguji apakah dalam model regresi, variabel pengganggu atau residual memiliki distribusi normal. Hasil uji Kolmogorof Smirnov dapat dilihat pada tabel berikut :

Tabel 2

Kolmogorov Smirnov

One-Sample Kolmogorov-Smirnov Test

\begin{tabular}{|ll|r|}
\hline & & $\begin{array}{c}\text { Unstandardized } \\
\text { Residual }\end{array}$ \\
\hline $\mathrm{N}$ & Mean & 165 \\
Normal Parameters ${ }^{\mathrm{a}, \mathrm{b}}$ & Std. Deviation & .01135744 \\
& Absolute & .073 \\
& Positive & .073 \\
Most Extreme Differences & -.072 \\
& Negative & .943 \\
Kolmogorov-Smirnov Z & & .336 \\
Asymp. Sig. (2-tailed) & & \\
a. Test distribution is Normal. & \\
b. Calculated from data. &
\end{tabular}

Berdasarkan hasil uji normalitas diketahui nilai signifikansi $0.336>0.05$ maka dapat disimpulkan bahwa residual berdistribusi normal. Hal ini sesuai dengan teori Santoso (2016:291) yang menyatakan bahwa jika probabilitas > 0,05 maka distribusi dari model regresi adalah normal dan jika probabilitas <
0,05 maka distribusi dari model regresi adalah tidak normal.

\section{b. Pengujian Grafik P-Plot}

Pengujian normalitas yang dilakukan dengan menggunakan pengujian grafik P-P Plot untuk pengujian residual model regresi dapat dilihat pada gambar berikut : 

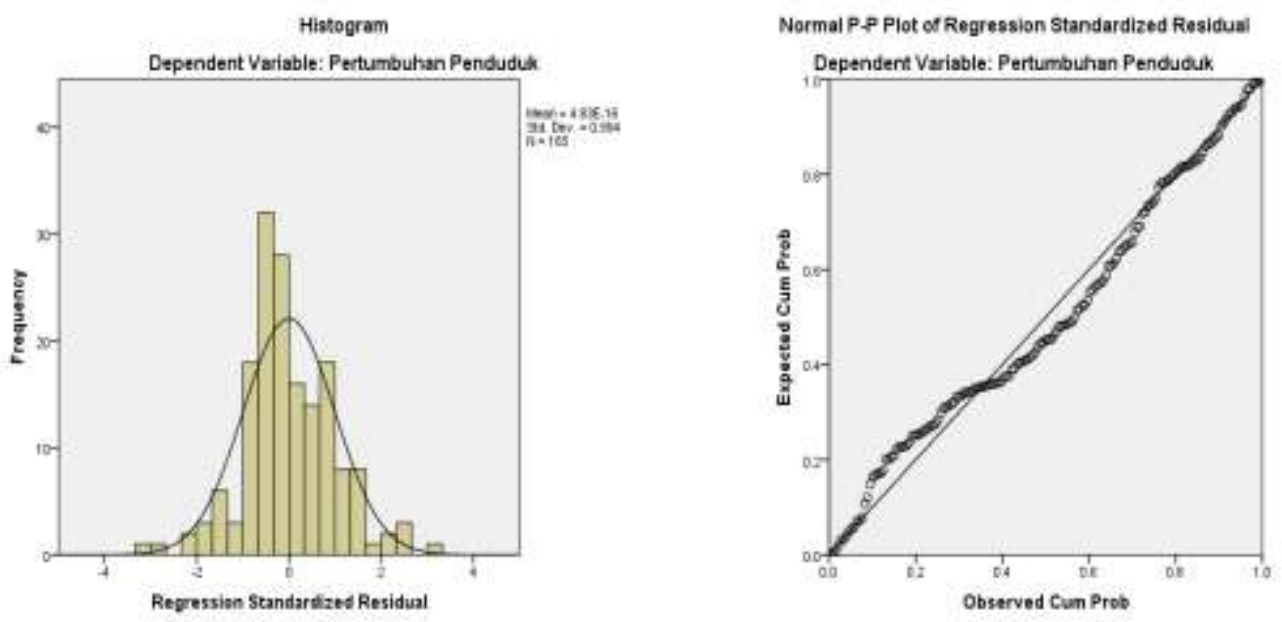

Gambar 1.Grafik Normal Probability Plot

Pada gambar di atas dapat dilihat bahwa Grafik normal probability plot menunjukkan bahwa data menyebar di sekitar garis diagonal dan mengikuti arah garis diagonal. Pada histogram juga terlihat bahwa distribusi membentuk lonceng, hal ini secara subyektif dapat disimpulkan bahwa data berdistribusi normal. Hal ini sesuai dengan teori Menurut Santoso (2016:293) yang menyatakan bahwa apablia data menyebar di sekitar garis diagonal dan mengikuti arah garis diagonal serta gambar

\section{Tabel 3}

Uji Multikilinieritas

Coefficients $^{\mathrm{a}}$

\begin{tabular}{|rl|r|c|}
\hline \multirow{2}{*}{ Model } & \multicolumn{2}{|c|}{ Collinearity Statistics } \\
\cline { 3 - 4 } & & Tolerance & \multicolumn{1}{c|}{ VIF } \\
\hline \multirow{3}{*}{1} & (Constant) & & \\
& Penggunaan Alat & .971 & 1.029 \\
& Kontrasepsi & .971 & 1.029 \\
\hline
\end{tabular}

a. Dependent Variable: Pertumbuhan Penduduk

Tabel di atas menunjukkan bahwa variabel memiliki nilai VIF lebih kecil dari 10 dan nilai tolerance yang lebih kecil dari $10 \%$, yang berarti bahwa tidak terdapat korelasi antar variabel. Sehingga dari hal tersebut di atas dapat disimpulkan bahwa tidak terdapat multikolinearitas antar variabel bebas dalam model regresi.

\section{d. Uji Heterokedastisitas}

Uji heteroskedastisitas menghasilkan grafik pola penyebaran titik (scatterplot) seperti tampak pada Gambar 2 berikut. histogram membentuk lonceng maka model regresi memenuhi asumsi normalitas.

\section{c. Uji Multikolinieritas}

Untuk dapat menentukan apakah terdapat multikolinearitas dalam model regresi pada penelitian ini adalah dengan melihat nilai VIF (Variance Inflation Factor) dan tolerance. Adapun nilai VIF dapat dilihat pada tabel dibawah ini.

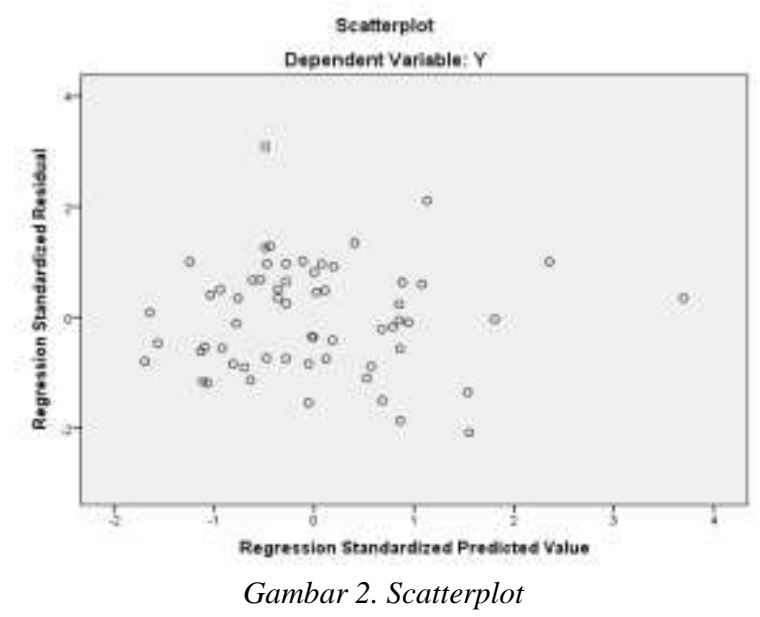


Hasil pengujian heteroskedastisitas menunjukkan bahwa titik-titik tidak membentuk pola tertentu atau tidak ada pola yang jelas serta titik-titik menyebar di atas dan e. Uji Autokorelasi dibawah angka 0 (nol) pada sumbu Y, maka tidak terjadi heteroskedastisitas.

Tabel 4

Uji Autokorelasi

Model Summary ${ }^{\mathrm{b}}$

\begin{tabular}{|l|r|r|r|r|r|}
\hline Model & \multicolumn{1}{|c|}{$\mathrm{R}$} & $\mathrm{R}$ Square & \multicolumn{1}{c|}{$\begin{array}{c}\text { Adjusted R } \\
\text { Square }\end{array}$} & $\begin{array}{c}\text { Std. Error of the } \\
\text { Estimate }\end{array}$ & Durbin-Watson \\
\hline 1 & $.738^{\mathrm{a}}$ & .544 & .539 & .01143 & 1.819 \\
\hline
\end{tabular}

a. Predictors: (Constant), Migrasi Penduduk, Penggunaan Alat Kontrasepsi

b. Dependent Variable: Pertumbuhan Penduduk

Pengujian menggunakan uji Durbin Watson yang hasilnya ditunjukkan pada tabel sebagai berikut. Nilai DW sebesar 1.819, nilai ini akan dibandingkan dengan nilai tabel dengan menggunakan signifikansi $5 \%$. Untuk jumlah sampel $\mathrm{n}=165$, nilai $\mathrm{dl}=1.7209$ dan $\mathrm{du}=$ 1.7700. Nilai 4-dl $(4-1.7209)=2.2791$ dan nilai $4-\mathrm{du}(4-1.7700)=2.2300$.

Maka dari hasil perhitungan di atas bahwa nilai DW sebesar 1.819 terletak antara du dan (4-du) sebesar 1.7700 dan 2.2300 (du < DW < 4-du) maka dapat disimpulkan bahwa tidak ada autokorelasi dalam model regresi yang digunakan dalam penelitian ini.

Dengan demikian, asumsi-asumsi normalitas, multikolinearitas dan heteroskedastisitas dalam model regresi dapat dipenuhi dari model ini.

\subsection{Hasil Regresi Linier Berganda}

Hasil analisis regresi dengan menggunakan bantuan SPSS dapat dilihat pada tabel sebagai berikut:

Tabel 5

Analisis Regresi Linier Berganda Coefficients $^{\mathrm{a}}$

\begin{tabular}{|c|c|c|c|c|c|c|}
\hline \multirow{2}{*}{\multicolumn{2}{|c|}{ Model }} & \multicolumn{2}{|c|}{$\begin{array}{l}\text { Unstandardized } \\
\text { Coefficients }\end{array}$} & \multirow{2}{*}{$\begin{array}{c}\begin{array}{c}\text { Standardize } \\
\mathrm{d} \\
\text { Coefficients }\end{array} \\
\text { Beta }\end{array}$} & \multirow[t]{2}{*}{$\mathrm{t}$} & \multirow[t]{2}{*}{ Sig. } \\
\hline & & $\bar{B}$ & $\begin{array}{c}\text { Std. } \\
\text { Error }\end{array}$ & & & \\
\hline \multirow{3}{*}{1} & (Constant) & .003 & .003 & & 1.157 & .249 \\
\hline & $\begin{array}{l}\text { Penggunaan Alat } \\
\text { Kontrasepsi }\end{array}$ & $-3.077 \mathrm{E}-007$ & .000 & -.470 & -8.734 & .000 \\
\hline & Migrasi Penduduk & 5.692E-006 & .000 & .495 & 9.189 & .000 \\
\hline
\end{tabular}

a. Dependent Variable: Pertumbuhan Penduduk

Berdasarkan tabel diatas terdapat beberapa kolom dalam tabel Coefficients di atas didapat nilai persamaan regresi $Y=a+b_{1} X_{1}+b_{2} X_{2}+e$ sehingga didapatkan persamaan regresi $\mathrm{Y}=$ $0.003-3.077 \mathrm{X}_{1}+5.692 \mathrm{X}_{2}+\mathrm{e}$ dimana dalam kolom Constant adalah 0.003, Pemggunaan Alat Kontrasepsi (-3.077), Migrasi Penduduk (5.692). Persamaaan regresi linier berganda tersebut, dapat diartikan sebagai berikut :

1) Nilai konstanta (a) adalah 0.003. Artinya jika variabel Penggunaan Alat Kontrasepsi $\left(\mathrm{X}_{1}\right)$, Migrasi Penduduk $\left(\mathrm{X}_{2}\right)$, nilainya adalah 0 , maka nilainya positif, yaitu 0.003 .
2) Nilai koefisien regresi variabel Penggunaan Alat Kontrasepsi $\left(\mathrm{X}_{1}\right)$ bernilai negatif, yaitu -3.077. Artinya bahwa apabila ada peningkatan Penggunaan Alat Kontrasepsi $\left(\mathrm{X}_{1}\right)$ sebesar 1\%, maka Pertumbuhan Penduduk akan mengalami penurunan sebesar 3.077 dengan asumsi variabel lain bernilai konstan.

3) Nilai koefisien regresi variabel Migrasi Penduduk $\left(\mathrm{X}_{2}\right)$ bernilai positif, yaitu 5.692. Artinya bahwa apabila ada peningkatan Migrasi Penduduk $\left(\mathrm{X}_{2}\right)$ sebesar $1 \%$, maka Pertumbuhan Penduduk akan meningkat 
sebesar 5.692 dengan asumsi variabel lain bernilai konstan.

\subsection{Hasil Uji Parsial (Uji T)}

Hasil Uji Parsial dengan menggunakan bantuan SPSS dapat dilihat pada tabel sebagai berikut:

Tabel 6

Uji Parsial (Uji t)

Coefficients $^{\mathrm{a}}$

\begin{tabular}{|c|c|c|c|c|c|c|}
\hline \multirow{2}{*}{\multicolumn{2}{|c|}{ Model }} & \multicolumn{2}{|c|}{$\begin{array}{l}\text { Unstandardized } \\
\text { Coefficients }\end{array}$} & \multirow{2}{*}{$\begin{array}{c}\begin{array}{c}\text { Standardize } \\
\mathrm{d} \\
\text { Coefficients }\end{array} \\
\text { Beta }\end{array}$} & \multirow[t]{2}{*}{$\mathrm{t}$} & \multirow[t]{2}{*}{ Sig. } \\
\hline & & B & $\begin{array}{l}\text { Std. } \\
\text { Error }\end{array}$ & & & \\
\hline \multirow{3}{*}{1} & (Constant) & .003 & .003 & & 1.157 & .249 \\
\hline & $\begin{array}{l}\text { Penggunaan Alat } \\
\text { Kontrasepsi }\end{array}$ & $-3.077 \mathrm{E}-007$ & .000 & -.470 & -8.734 & .000 \\
\hline & Migrasi Penduduk & 5.692E-006 & .000 & .495 & 9.189 & .000 \\
\hline
\end{tabular}

Output dari tabel 6 dapat dilihat nilai thitung yang diperoleh setiap variabel. Dengan menggunakan tingkat signifikansi sebesar 5\% dandiperoleh nilai t-tabel sebesar 1.65437. Untuk kriteria Uji t, t tabel dilakukan pada tingkat $\alpha=5 \%$. Nilai $\mathrm{t}=(\alpha ; \mathrm{n}-\mathrm{k}-1)=(0.05$; $165-3-1)=161=(0.05 ; 161)=1.65437$.

Hasil pengujian pengaruh Penggunaan Alat Kontrasepsi dan Migrasi Penduduk terhadap Pertumbuhan Penduduk adalah sebagai berikut:

1) Pengaruh Penggunaan Alat Kontrasepsi $\left(X_{1}\right)$ terhadap Pertumbuhan Penduduk

Hasil analisis diperoleh nilai $\mathrm{t}_{\text {hitung }}$ untuk variabel Penggunaan Alat Kontrasepsi $\left(\mathrm{X}_{1}\right)$ sebesar -8.734 jika dibandingkan dengan nilai $t_{\text {tabel }}$ yang sebesar 1.65437. Maka $t_{\text {hitung }}$ yang diperoleh lebih besar dari nilai $t_{\text {tabel }}$ atau $-8.734>1.65437$ kemudian terlihat pula bahwa nilai sig lebih kecil dari nilai

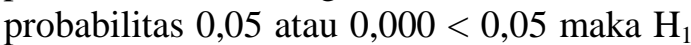
diterima sehingga variabel $\mathrm{X}_{1}$ memiliki kontribusi terhadap Y. Jadi dapat berikut:

Tabel 7

Uji Simultan (Uji f)

ANOVA $^{\mathrm{a}}$ disimpulkan variabel Penggunaan Alat Kontrasepsi berpengaruh negatif dan signifikan terhadap Pertumbuhan Penduduk.

2) Pengaruh Migrasi Penduduk $\left(X_{2}\right)$ terhadap Pertumbuhan Penduduk

Hasil analisis diperoleh nilai $t_{\text {hitung }}$ untuk variabel Migrasi Penduduk $\left(\mathrm{X}_{2}\right)$ sebesar 9.189 jika dibandingkan dengan nilai $\mathrm{t}_{\text {tabel }}$ yang sebesar 1.65437. Maka $t_{\text {hitung }}$ yang diperoleh lebih besar dari nilai $t_{\text {tabel }}$ atau $9.189>1.65437$ kemudian terlihat pula bahwa nilai sig lebih kecil dari nilai probabilitas 0,05 atau $0.000<0,05$ maka $\mathrm{H}_{2}$ diterima sehingga variabel $\mathrm{X}_{2}$ memiliki kontribusi terhadap Y. Jadi dapat disimpulkan variabel Migrasi Penduduk positif dan signifikan berpengaruh terhadap Pertumbuhan Penduduk.

\subsubsection{Hasil UjiSimultan (Uji F)}

Hasil Uji Simultan dengan menggunakan bantuan SPSS dapat dilihat pada tabel sebagai

\begin{tabular}{|c|c|c|c|c|c|c|}
\hline \multicolumn{2}{|c|}{ Model } & Sum of Squares & $\overline{d f}$ & $\begin{array}{c}\text { Mean } \\
\text { Square }\end{array}$ & $\bar{F}$ & Sig. \\
\hline \multirow{3}{*}{1} & Regression & .025 & 2 & \multirow{3}{*}{$\begin{array}{l}.013 \\
.000\end{array}$} & \multirow[t]{3}{*}{96.691} & \multirow[t]{3}{*}{$.000^{6}$} \\
\hline & Residual & .021 & 162 & & & \\
\hline & Total & .046 & 164 & & & \\
\hline
\end{tabular}

Berdasarkan tabel 7 dapat dilihat $\mathrm{f}$ hitung adalah 96.691 dengan $\alpha 5 \%$, dk pembilang : 2 , $\mathrm{dk}$ penyebut : 165 sehingga 165-2-1 = 162 $\left(0.05 ; 2 ; 162 ; \mathrm{F}_{\text {tabel }} 3.05\right)$ sehingga diperoleh nilai $\mathrm{F}_{\text {tabel }}$ sebesar 3.05. Berdasarkan uraian tersebut dapat diketahui bahwa $F_{\text {hitung }}$ (96.691) 
$>F_{\text {tabel }}$ (3.05), dan nlai signifikansi sebesar $0.000<0.05$ maka dapat disimpulkan hipotesis ketiga diterima, artinya variabel Penggunaan Alat Kontrasepsi $\left(\mathrm{X}_{1}\right)$ dan Migrasi Penduduk
$\left(\mathrm{X}_{2}\right)$ berpengaruh secara bersama-sama (simultan) terhadap variabel Pertumbuhan Penduduk (Y).

\title{
3.3. Koefisien Determinasi $\left(\mathbf{R}^{2}\right)$
}

\author{
Tabel 8
}

Uji Koefisien Determinasi Model Summary ${ }^{\mathrm{b}}$

\begin{tabular}{|l|r|r|r|r|r|}
\hline Model & \multicolumn{1}{|c|}{$\mathrm{R}$} & R Square & \multicolumn{1}{c|}{$\begin{array}{c}\text { Adjusted R } \\
\text { Square }\end{array}$} & $\begin{array}{c}\text { Std. Error of the } \\
\text { Estimate }\end{array}$ & Durbin-Watson \\
\hline 1 & $.738^{\mathrm{a}}$ & .544 & .539 & .01143 & 1.819 \\
\hline
\end{tabular}

a. Predictors: (Constant), Migrasi Penduduk, Penggunaan Alat Kontrasepsi

b. Dependent Variable: Pertumbuhan Penduduk

Berdasarkan Tabel di atas dapat diketahui nilai $\mathrm{R}$ square sebesar 0.544 . Hal ini berarti bahwa pengaruh variabel bebas terhadap variable terikat adalah sebesar $54.4 \%$, sedangkan sisanya sebesar 0.456 atau $45.6 \%$ dipengaruhi variable lain yang tidak dimasukkan dalam penelitian ini.

\subsection{Evaluasi Data}

\subsubsection{Pengaruh Penggunaan Alat} Kontrasepsi Terhadap Pertumbuhan Penduduk

Hasil analisis diperoleh nilai $t_{\text {hitung }}$ untuk variabel Penggunaan Alat Kontrasepsi $\left(\mathrm{X}_{1}\right)$ sebesar -8.734 jika dibandingkan dengan nilai $t_{\text {tabel }}$ yang sebesar 1.65437. Maka $t_{\text {hitung }}$ yang diperoleh lebih besar dari nilai $\mathrm{t}_{\text {tabel }}$ atau -8.734 $>1.65437$ kemudian terlihat pula bahwa nilai sig lebih kecil dari nilai probabilitas 0,05 atau $0,000<0,05$ maka $\mathrm{H}_{1}$ diterima sehingga variabel $\mathrm{X}_{1}$ memiliki kontribusi terhadap $\mathrm{Y}$. Jadi dapat disimpulkan variabel Penggunaan Alat Kontrasepsi berpengaruh negatif dan signifikan terhadap Pertumbuhan Penduduk. Penggunaan alat kontrasepsi adalah salah satu cara dari program keluarga berencana dimana merupakan satu upaya pemerintah untuk mengendalikan jumlah pertumbuhan penduduk. Penggunaan alat kontrasepsi telah diyakini telah berkontribusi terhadap penurunan tingkat kelahiran, yang selanjutnya mengakibatkan penurunan jumlah pertumbuhan penduduk, terutama di Negara-negara berkembang, termasuk Indonesia. Selanjutnya, di Negaranegara dengan tingkat kelahiran dan tingkat kematian tinggi. Dalam upaya pencapaian tujuan pembangunan melenium, terutama tujuan penurunan kemiskinan dan penurunan tingkat kematian ibu dan anak usia balita. Hal ini sejala dengan penelitian yang dilakukan oleh Fitri (2018) yang mengatakan bahwa program BKKBN cukup efektif dalam mengendalikan pertumbuhan penduduk di Kota Makassar Provinsi Sulawesi Selatan.

\subsubsection{Pengaruh Migrasi Terhadap Pertumbuhan Penduduk}

Hasil analisis diperoleh nilai $\mathrm{t}_{\text {hitung }}$ untuk variabel Migrasi Penduduk $\left(\mathrm{X}_{2}\right)$ sebesar 9.189 jika dibandingkan dengan nilai $t_{\text {tabel }}$ yang sebesar 1.65437. Maka $t_{\text {hitung }}$ yang diperoleh lebih besar dari nilai $t_{\text {tabel }}$ atau $9.189>1.65437$ kemudian terlihat pula bahwa nilai sig lebih kecil dari nilai probabilitas 0,05 atau $0.000<$ 0,05 maka $\mathrm{H}_{2}$ diterima sehingga variabel $\mathrm{X}_{2}$ memiliki kontribusi terhadap Y. Jadi dapat disimpulkan variabel Migrasi Penduduk positif dan signifikan berpengaruh terhadap Pertumbuhan Penduduk.

Adanya perpindahan penduduk menyebabkan meningkatnya jumlah penduduk didaerah tujuan, sehingga penduduk daerah tujuan yang sudah padat menjadi semakin padat, sehingga tingkat pertumbuhan penduduk meningkat tajam didaerah tujuan. Meningkatnya jumah migrasi masuk menyebabkan meningkatkatnya perubahan lahan dan fungsi bangunan. Todaro (2014) menjelaskan bahwa pertumbuhan migrasi dari desa ke kota yang terus menerus meningkat merupakan penyebab utama semakin banyaknya pemukiman-pemukiman kumuh di perkotaan. Pesatnya pertumbuhan penduduk kota sebagai dampak dari urbanisasi ini mengakibatkan munculnya kebutuhan akan rumah sebagai tempat bermukim atau tempat usaha. Pengalihan fungsi bangunan untuk tempat usaha baik sebagai tempat kos maupun 
tempat usaha dagang atau jasa untuk meningkatkan pendapatan keluarga. Hal ini sejalan dengan penelitian yang dilakukan oleh Suartha (2017) tentang Pengaruh Pertumbuhan Ekonomi dan Migrasi Masuk terhadap Pertumbuhan Penduduk dan Ahli Fungsi Bangunan Penduduk Asli Kota Denpasar yang menemukan bawaha Migrasi memiliki pengaruh positif dan signifikan terhadap Pertumbuhan Penduduk.

\section{Kesimpulan}

1. Berdasarkan hasil pengujian secara parsial dikertahui bahwa variabel Penggunaan Alat Kontrasepsi $\left(\mathrm{X}_{1}\right)$ dan Migrasi Penduduk $\left(\mathrm{X}_{2}\right)$ memiliki pengaruh terhadap Pertumbuhan Penduduk (Y).

2. Berdasarkan hasil uji simultan diperoleh bahwa $F_{\text {hitung }}(96.691)>F_{\text {tabel }}(3.05)$, dan nlai signifikansi sebesar $0.000<0.05$ maka dapat disimpulkan hipotesis ketiga diterima, artinya variabel Penggunaan Alat Kontrasepsi $\left(\mathrm{X}_{1}\right)$ dan Migrasi Penduduk $\left(\mathrm{X}_{2}\right)$ berpengaruh secara bersama-sama (simultan) terhadap variabel Pertumbuhan Penduduk (Y).

3. Berdasarkan hasil uji koefisien determinasi diperoleh nilai $\mathrm{R}$ square sebesar 0.544 . Hal ini berarti bahwa pengaruh variabel bebas terhadap variable terikat adalah sebesar $54.4 \%$, sedangkan sisanya sebesar 0.456 atau $45.6 \%$ dipengaruhi variable lain yang tidak dimasukkan dalam penelitian ini.

\section{DAFTAR PUSTAKA}

Almaulida, D. N., Putro, S., \& Hardati, P. 2018. Faktor-Faktor yang Mempengaruhi Laju Pertumbuhan Penduduk di Kecamatan Bawen Kabupaten Semarang Tahun 20002015. Geo Image, Vol. 7(No. 2).

Azuar Juliandi, I. 2016. Metodologi Penelitian Kuantitatif untuk Ilmu-Ilmu Bisnis. Bandung: Citapustaka Media Perintis.

Badan Pusat Statistik. 2011. Sistem Informasi Rujukan Statistik - View Indikator. https://sirusa.bps.go.id/sirusa/index.php/indi kator/48.

BKKBN. 2019. Memperkuat Pemakaian Kontrasepsi, Menjaga Bonus Demografi. https://www.bkkbn.go.id/detailpost/memper kuat-pemakaian-kontrasepsi-menjagabonus-demografi.

Ghozali, I. 2020. Aplikasi Analisis Multivariate dengan Program IBM SPSS
26. Semarang: BPFE Universitas Diponegoro.

Honestdoxs. 2019. Survei Alat Kontrasepsi Populer di Indonesia. Jakarta: Honestdocs.id.

James, M., \& Todaro, M. P. 2014. Pembangunan Ekonomi di Dunia Ketiga. Economic Development. Jakarta: Ghalia Indonesia. https://doi.org/2003.

Mantra, B. 2010. Demografi Umum. Yogyakarta: Pustaka Pelajar.

Munir, R. 2010. Dasar-Dasar Demografi. Jakarta: UI Press.

Nugroho, \& Utama. 2014. Masalah Kesehatan Reproduksi Wanita. Yogyakarta: Nuha Medika.

Pemprov Sumut. 2017. Rencana Kerja Pemerintah Daerah Provinsi Sumatera Utara. Sumatera Utara: Pemerintah Provinsi Sumatera Utara.

Sarsanto. 2007. Pelayanan Keluarga Berencana (KB). Jakarta: EGC.

Suartha, N. 2016. Faktor-Faktor yang Mempengaruhi Tingginya Laju Pertumbuhan dan Implementasi Kebijakan Penduduk di Provinsi Bali. PIRAMIDA, Vol. 12(No. 1).

Suartha, N., \& Yasa, I. G. W. M. 2017. Pengaruh Pertumbuhan Ekonomi, Migrasi Masuk terhadap Pertumbuhan Penduduk dan Alih Fungsi bangunan Penduduk Asli Kota Denpasar. JEKT, Vol. 10(No. 2).

Sugiyono. 2017. Metode Penelitian Kuantitatif, Kualitatif dan $R \quad \& \quad D$. Bandung: Alfabeta.

Wiknjosastro, H. 2014. Ilmu Kebidanan. Jakarta: Yayasan Bina Pustaka.

Zulfa, A. 2016. Pengaruh Pertumbuhan Penduduk dan Pertumbuhan Ekonomi terhadap Tingkat Pengangguran di Kota Lhokseumawe. E-Journal, Vol. 2(No. 1). 